Web Site: https://jutq.utq.edu.iq/index.php/main Email: journal@jutq.utq.edu.iq

\title{
Parasitic infections causing diarrhoea among children less than six years at Al-Nasiriya province https://doi.org/10.32792/utq/utj/vol11/4/10
}

\author{
Khwam R. Hussein ${ }^{1 *}$, Hayat N Dahis ${ }^{1}$, Abdul -Kareem A. \\ Mshhwt $^{1}$ \\ ${ }^{1}$ Medical Dep., Al-Nasiriya Technical Institute, Southern \\ Technical University, Post code: 64001, Iraq. \\ *Corresponding author: khwamhussein@gmail.com \\ Mobile: +9647811060099
}

\begin{abstract}
This study aimed to determine the parasitic agents of diarrhoea in children aged less than six years. Out of 780 cases of diarrhea, 206 (26.41\%) had one or more parasitic infections and the remaining $574(73.58 \%)$ had other enteropathogenic agents of diarrhoea. There were $166(21.98 \%)$ protozoal infections and $40(5.12 \%)$ helminthes. Male children were 113(45.8\%) and females were 93(44.68 \%). The most common pathogens were Giardia lamblia 117 (56.79 \%); Entamoeba histolytica 49 (23.78\%); Enterobius vermicularis 27 (13.10\%); Ascaris lumbricoides 9 (4.36 \%) and Hymenolepis nana 4 (1.94\%). Moreover, the highest parasitic infections observed during summer months with bottle-feeding nutrition.
\end{abstract}

Key words: Diarrhoea; parasites; children. 


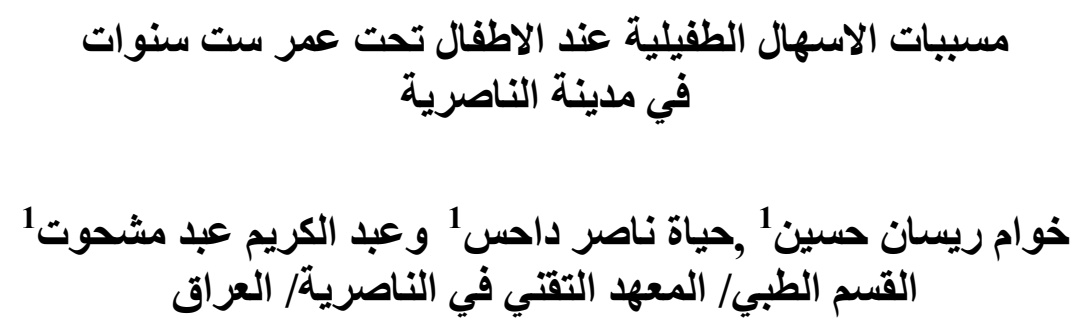

الخلاصة

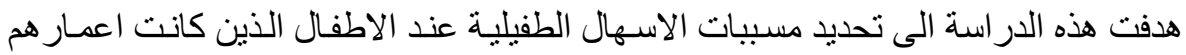

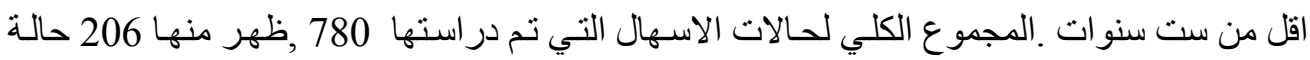

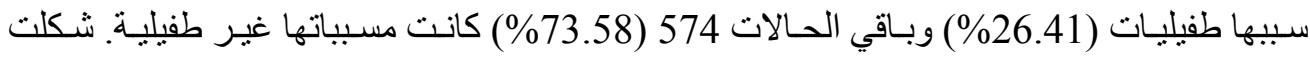

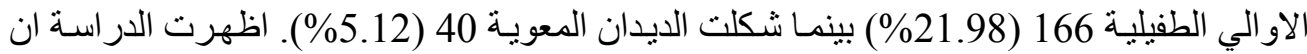

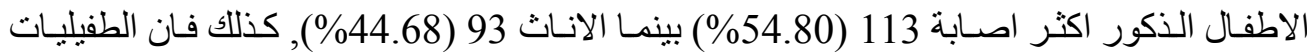

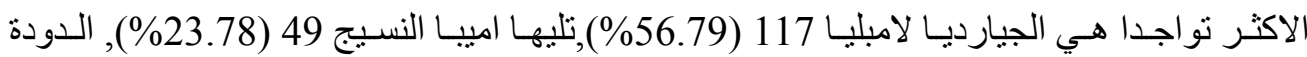

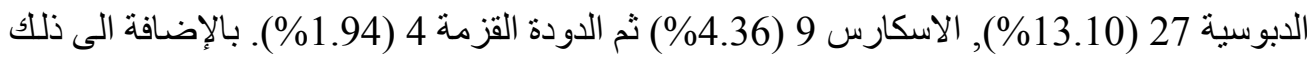

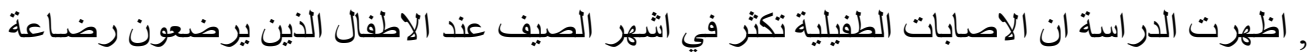
اصطناعية.

\section{Introduction}

Diarrhoea, especially in children, is a major cause of morbidity and mortality in developing countries; every year more than 1.5 million children under the age of five years die as a result of acute diarrhoea despite the availability of effective low cost therapies to manage diarrhoea cases (Kebede et al., 2004). Diarrhoea can be caused by a wide range of viruses, bacteria, or parasites (Moyo et al., 2011). Intestinal parasites are common in Iraq (Kadir et al., 1993). Intestinal parasites are common in the developing world, presumably due to poor environmental and personal hygiene which largely caused by sewage disposal and inadequate water supply (Magambo et al., 1998; Tinuade et al., 2006). A large proportion of diarrhoea diseases in children are infective in origin but the etiologies, a few years ago, were largely underdetermined for lack of facilities. Recently, the role of viral agents, especially the Rotavirus as the main causes of childhood diarrhoea, and this has broadened the etiological scope in diarrhoea especially in children (Yousef et al., 2000). On the other hand, under-nutrition remains one of the most serious health problems among preschool children and the single main 


\section{University of Thi-Qar Journal Vol.11 No.4 DEC 2016}

Web Site: https://jutq.utq.edu.iq/index.php/main Email: journal@jutq.utq.edu.iq

contributor to child mortality in many low and middle income Arab countries (Musaiger et al., 2011). The aim of this study is to evaluate parasitic enteropathogens among Iraqi children with diarrhoea and to observe a relationship between the type of feeding and parasitic infections especially at Al-Nasiriyah city.

\section{Materials and methods}

This study was carried out at Al-Habobbi Hospital for children and maternity at Al-Nasiriya province from January to August 2008 (8 months period). One hundred and thirteen patients were males and 93 were females, their age ranged from one day to six years. The age, gender, nutritional status, history of breastfeeding and bottle-feeding were obtained for children aged 24 months and below and day care attendance for those aged 36 months and below. Fresh stool specimens were collected directly in sterile screw capped containers and examined microscopically (within 30 minutes) by a direct method using $0.85 \%$ saline and lugoles iodine solution (Sood, 2006). Identification of parasites was based on the cysts and trophozoites with respect to protozoal and ova as helminthes parasite (Heyneman, 2004; Forbes et al., 2007) and for the collection of ova of Enterobius vermicularis we used the Scotch tape method (Paniker, 2007). The data were analyzed statistically by SPSS statistical programme (version 18), and the comparison between the groups and the relationship were obtained. A p value equal or less than 0.05 was considered to indicate a statistically significant difference.

\section{Results}

Over the period of 8 months, 780 children less than six years old were exhibited with acute diarrhoea. Parasitic agents were identified in 206 (26.41 $\%)$ stool samples while the remaining $574(73.58 \%)$ had no identifiable parasitic agents. The males children were $113(54.8 \%)$ and the females were $93(44.6 \%)$ (Table 1$)$.

Table 1: Distribution of patients according to gender and age groups

\begin{tabular}{l|ll}
\hline Age groups year & Males & Females \\
\hline
\end{tabular}


Web Site: https://jutq.utq.edu.iq/index.php/main Email: journal@jutq.utq.edu.iq

\begin{tabular}{c|cc}
\hline$>1$ & 8 & 6 \\
1 to $>2$ & 25 & 17 \\
2 to $>3$ & 22 & 18 \\
3 to $>4$ & 24 & 16 \\
4 to $>5$ & 18 & 20 \\
5 to $>6$ & 16 & 16 \\
\hline Total & 113 & 93 \\
\hline P $<0.05$
\end{tabular}

Table 2 shows the age and the types of parasite, and regarding the majority of cases infections were in age group (1-2 years) and the study indicates that Giardia lamblia $(56.79 \%$ ) represented the highest rate of infection followed by Entamoeba histolytica (23.78 \%); Enterobius vermicularis (13.10\%); Ascaris lumbricoides 9 (4.36\%) and Hymenolepis nana 4 (1.94\%). Figure 1 shows that the incidence of infections with intestinal parasites was obviously high in summer months and among the bottle-feeding children was less than 24 months (Figure 2).

Table 2: Distribution of intestinal parasites among different age groups

\begin{tabular}{c|ccccccccc}
\hline $\begin{array}{c}\text { Age } \\
\text { group/year }\end{array}$ & \multicolumn{2}{|c}{ G.lambelia } & \multicolumn{2}{c}{ E.histolytica } & $\begin{array}{c}E . \\
\text { vermicularis }\end{array}$ & $\begin{array}{c}A . \\
\text { lumbricoides }\end{array}$ & $\begin{array}{c}H \\
\text { nana }\end{array}$ & \multicolumn{2}{c}{ Total } \\
\hline & C $^{*}$ & T $^{* *}$ & C & T & Ova & Ova & Ova & No & $\%$ \\
$<1$ & 5 & 6 & 1 & 1 & 1 & - & - & 14 & 6.8 \\
1 to $<2$ & 16 & 13 & 6 & 4 & 3 & - & - & 42 & 20.3 \\
2 to $<3$ & 11 & 13 & 5 & 6 & 4 & 1 & - & 40 & 19.4 \\
3 to $<4$ & 12 & 11 & 3 & 4 & 6 & 3 & 1 & 40 & 19.4 \\
4 to $<5$ & 10 & 9 & 3 & 5 & 8 & 2 & 1 & 38 & 18.4 \\
5 to $<6$ & 7 & 4 & 5 & 6 & 5 & 3 & 2 & 32 & 15.5 \\
\hline Total & 61 & 56 & 23 & 26 & 27 & 9 & 4 & 206 & 100 \\
\hline
\end{tabular}

${ }^{*} \mathrm{C}$ : cyst $; * *$ T: trophozoite; $p<0.05$ 
University of Thi-Qar Journal Vol.11 No.4 DEC 2016

Web Site: https://jutq.utq.edu.iq/index.php/main Email: journal@jutq.utq.edu.iq

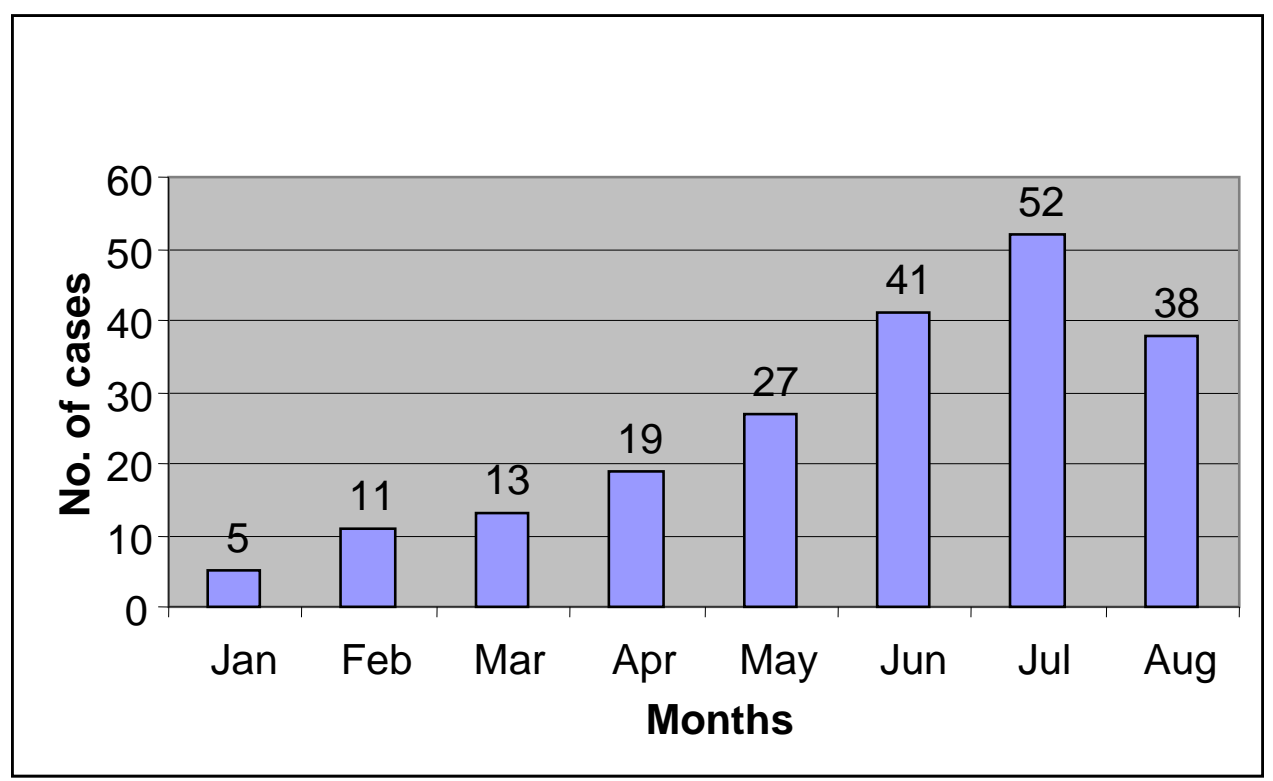

Figure 1: Incidence of parasites infections according to period of study

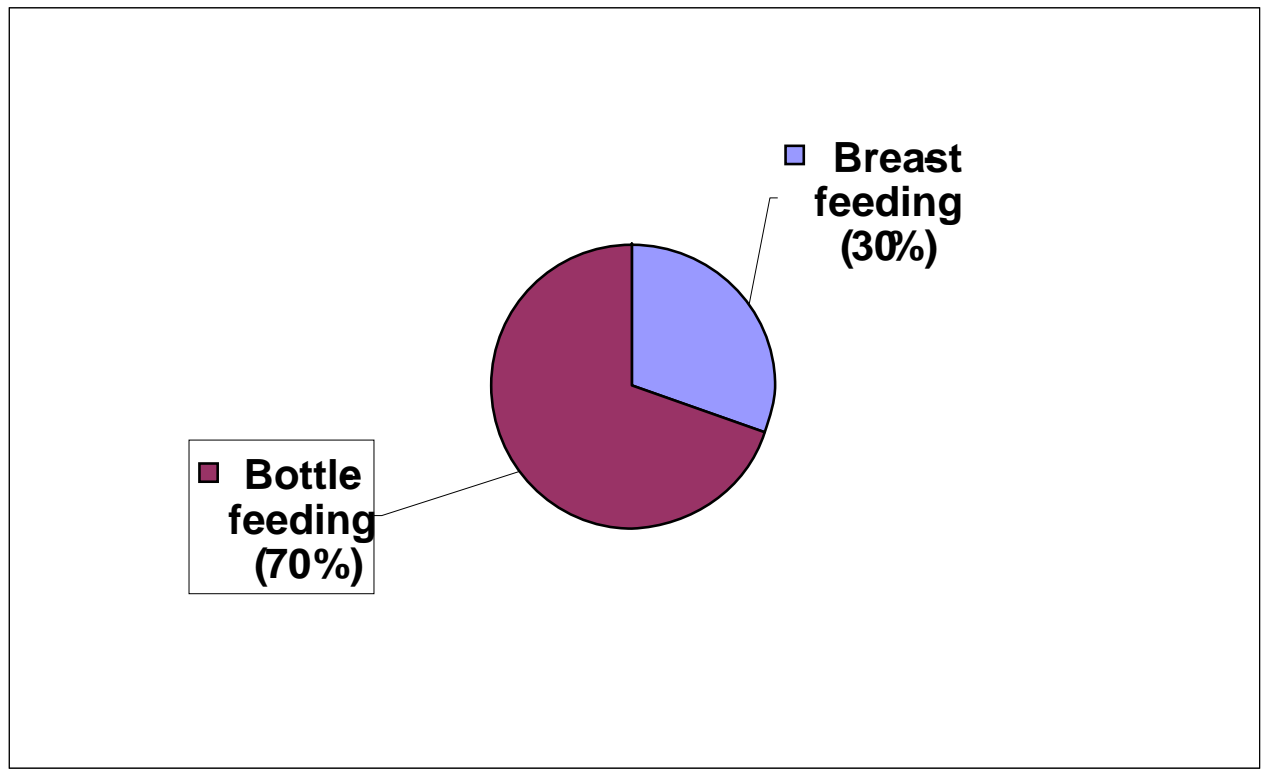

Figure 2: Illustration of feeding patterns among patients with diarrhea

\section{Discussion}




\section{University of Thi-Qar Journal Vol.11 No.4 DEC 2016}

Web Site: https://jutq.utq.edu.iq/index.php/main Email: journal@jutq.utq.edu.iq

The prevalence of intestinal parasites associated with children less than six years old diarrhoeal children in this study was lower $(26.41 \%)$, than the studies carried out by Adedoyin et al. (1990); Ighogbia and Ikeh (1997); Kaur et al. (2002) and Throen et al. (1982) who found that the percentage of infections were $32.5 \%, 30.7 \%, 46.3 \%$, and $70 \%$, respectively. This is may be related to geographical distribution.

Our results have shown that protozoa G. lamblia and E. histolytica were the most frequent among children. There are no significant differences between them that are prevalent over the helminthes. This goes with Kebede et al. (2004) and with Kadir et al. (1993). The incidence of infections in males was higher than in females; this finding goes with Mudher et al. (1987); Tinuade et al. (2006) and Prinker (2006) who found the highest incidence of parasitic infections in males. On the other hand, children under 24 months with the parasitic diarrhoea were higher in bottle-feeding (70 \%) than breast feeding children (30\%). This results agree with Tinuade et al. (2006) who referred to that bottle-feeding and early cessation of breast feeding were associated with parasitic diseases, because this kind of feeding which encouraged close contact with the parasites which are endemic in this environment.

The highest rate of infection was among children in the age group 1-2 years. There are no significant differences between them, and according to the age, this is in agreement with other reports (Kadir et al., 1993; Tinuade et al., 2006; Abu-Madi et al., 2010) who show that the increase of explorative tendencies at this age heightens the ova and cysts of parasites. Also, the rate of infection by cysts phase was greater by than trophozoite phase; this finding is similar to other studies (Lindo et al., 1998; Abu-Madi et al., 2010). The high incidence of parasitic diseases in summer months especially during fly seasons and poor hygiene as it is known that flies are capable of carrying cysts and contaminate the food and drink. Cysts are usually ingested through contaminated water, contaminated food; flies have been incriminating in areas of fecal pollution (Sood, 2006).

\section{Acknowledgments}

Thanks to the staff of the microbial laboratory in the Al-Habobbi Hospital for Children and Maternity. 
University of Thi-Qar Journal Vol.11 No.4 DEC 2016

Web Site: https://jutq.utq.edu.iq/index.php/main Email: journal@jutq.utq.edu.iq 


\section{References}

Abu-Madi, M. A.; Behnke, J. M. and Dorphode, S. H. (2010). Changing trends in intestinal parasitic infections among long-term-residents and settled immigrants in Qatar. Parasites \& Vectors, 3: 98-110.

Adedoyin, M.A.; Awogun, I.A.; Juergensen,T (1990) Prevalence of intestinal parasitoses in relashinship to diarrhoea among children in Ilorin. West. Afr. J. Med., 9: 83-88.

Heyneman, D. (2004) Medical parasitology, Section Vl, in: Brooks, G. F.; Buta, J. S. and Morse, S. A. Jawetz, Melnick And Adelberg`Medical microbiology. $23^{\text {rd }}$ edn. Mcgraw-Hill, New York, 818 pp.

Forbes, B.A; Sahm, D.F.; Weissfeld, A.S. and Trevino, E.A. (2007) Laboratory method for diagnosis of parasitic infection. in Bailey \& Scotts diagnostic microbiology. $12^{\text {th }}$ edn. Mosby Elsevier, Missouri, 1031 pp.

Ighogboja, I.S. and Ikeh,E.I. (1997) Parasitic agents in childhood diarrhoea and malnutrition. West Afr. J. Med., 16: 36-39.

Kadir, M.A. and Salman, Y.G. (1993) Prevalence of intestinal parasite, among primary school children in different localities of Al-Taemem province, Iraq. Annals Coll. Med. Mosul., 2: 18-25.

Kaur, R.; Rawat,D.; Kakkar, M.; Uppal, B. and Sharma, V. K. (2002) Intestinal parasites in children with Diarrhoea in Delhi, India. Southeastern. Asian J.Trop. Med. Public Health, 33: 725-729.

Kebede , A.; Polderman, A.M.; Okeke,I.N.; Ojo,O.; Lamikanra, A.; Kaper, J.B.E. (2004) Etiology of acute diarrhoea in adults in south - western Nigeria J.Clin. Microbiol. , 42:3909-3910.

Lindo, J.F; Levy,V.A; Baum, M.K. \& Palmer, C.J. (1998) Epidemiology of Giardiasis and Cryptospodiosis in Jamaica. Am. Trop. Med. Hyg., 59:717-721.

Magambo, J.K.; Zeyhle,E.;Wachira,T.M. (1998) Prevalence of Intestinal 
parasites among children in southern Sudan. East Afr. Med. J., 75: 288-290.

Moyo, S.J.; Gro, N.; Matee, M. I.; Kitundu, J.; Mylvaganam, H.; Maselle, S. and Langeland, N. (2011). Age specific aetiological agents of diarrhea in hospitalized children aged less than five years in Dar Salaam, Tanzania. BMC Pediatrics, 11: 19-25.

Mudher, M.F.; Munna, A.; Salmon,N.; Najim, N. and Jenan, S. (1987) A study of some enteropathogens isolated from children with diarrhoea in Baghdad. Basrah J. Med., 18:113-118,(1987).

Musaiger, A. O.; Hassan, A. S. and Obeid, O. (2011). The Paradox of NutritionRelated Diseases in the Arab Countries: The Need for Action. Int. J. Environ. Res. Public Health, 8: 3637-3671.

Paniker,J. Textbook of medical parasitology. Sixth edn. Jaypee Brothers , New Delhi, India. 235 pp.

Sood, R. (2006) Textbook of medical laboratory technology. $1^{\text {st }}$ edn. Jaypee Brothers, New Delhi, pp 1281.

Throen,A.; Stintzing,G.; Walder,M. and Habte,D. (1982) A etiology and clinical features of sever infantile diarrhoea in Addis Ababa, Ethiopia, J. Trop. Pediatr., 28: 127-131.

Tinuade, O.; John, O.; Saheed, O.; Oycku, O.; fidelis, N. and Olabisi, D. (2006) Parasite etiology of children diarrhoea. Indian J. Pediatr., 37: 1081-1084.

Yousef, M.; Shurman, A.; Bougnoux, M.; Bretagne, S.; Strockbine, N. (2000) Bacterial,viral and parasitic enteric pathogens associated with acute diarrhoea in hospitalized children from northern Jordan . FEMS Immunol .Med. Microbiol., 28: 257-262. 